\title{
Effect of enzymes on plasticity and strength characteristics of an earthen construction material
}

\author{
Sravan Muguda ${ }^{{ }^{*}}$ (D) and H. B. Nagaraj ${ }^{2}$
}

*Correspondence:
shravanmv@gmail.com
${ }^{1}$ Laboratoire SIAME
Université de Pau et des Pays
de l'Adour, 64600 Anglet,
France
Full list of author information
is available at the end of the
article

*Correspondence: shravanmv@gmail.com Université de Pau et des Pays de l'Adour, 64600 Anglet, article

\begin{abstract}
In this study, a commercially available enzyme which is used popularly to improve sub-grade material for pavements was used as a potential stabilizer to improve soil properties used for earthen construction. As a preliminary study, the interaction of this enzyme with the soil was assessed by evaluating the plasticity and strength characteristics of enzyme treated soil with ageing. From the research findings, it was observed that with ageing, the liquid limit of soil decreased, while plastic and shrinkage limits increased, leading to reduced plasticity and shrinkage indices. The reduced plasticity and shrinkage indices indicate that soil has become relatively more volumetrically stable and less susceptible to crack formation. Further, strength characteristics under two different curing conditions were evaluated, and it was found that under sealed curing conditions, the treated soil had better compressive strength. The improvement of plasticity, shrinkage and strength characteristics due to the addition of enzymes can be advantageously used for development of lightly stabilized durable earthen construction material, and thus, eliminating the necessity of using conventional energy-intensive stabilizers. The findings from this study bring the immense potential of eco-friendly enzymatic stabilization in the development of modern sustainable earthen materials.
\end{abstract}

Keywords: Enzymes, Plasticity, Stabilization, Strength, Sub-grade, Earthen materials

\section{Introduction}

In practice, chemical stabilizers such as cement and lime have been prevalently used to improve the engineering properties of the soil used in the preparation of earthen materials like compressed stabilized earth blocks (CSEBs), adobe blocks and rammed earth construction. Though this use has ensured in development of durable materials, the use itself has been criticized due to lack of sustainability [17]. To address this issue, there have been continuous research efforts to reduce the dependence on energy-intensive stabilizers. Alternatively, enzymes have been looked as viable economical alternatives to energy consuming stabilizers [3]. Enzymatic stabilizers have gained popularity, especially in the field of road construction for their simplicity in application and efficacy in stabilization [8, 9, 11-14, 18, 21, 31]. Enzymatic stabilizers are liquid organic compounds, which are inherently eco-friendly and non-toxic. Most researchers have reported promising effects of using enzymes in improving the soil properties $[2,4,14,19,28,35,36$, 42]. This improvement is due to the catalytic stabilization process of the enzyme with

(c) The Author(s) 2019. This article is distributed under the terms of the Creative Commons Attribution 4.0 International License (http://creativecommons.org/licenses/by/4.0/), which permits unrestricted use, distribution, and reproduction in any medium, provided you give appropriate credit to the original author(s) and the source, provide a link to the Creative Commons license, and indicate if changes were made. 
soil, and hence, very less quantity of stabilizer is required for stabilizing large amounts of soil $[34,35,41]$. With this enhancement, one can explore in the development of lightly stabilised earthen construction materials using only enzymes or reduce the quantity of chemical stabilisers in heavily stabilised earthen construction materials by adding enzymes. The authors have recently brought out one such possibility of using enzymes along with conventional stabilisers in development of durable compressed stabilised earth blocks [37, 38]. However, prior to its application as a stabiliser in earthen construction, it is important to understand more about the effect of enzymes and their effect on soil behaviour. This would provide useful insights for its practical large-scale application. This research article is aimed at understanding the effect of enzymes on soil plasticity and strength characteristics which in turn would provide potential guidelines for using enzymes as a stabiliser in earthen construction. The following section presents more details of enzyme stabilization.

\section{Enzyme-stabilization}

\section{Enzymatic soil stabilization}

Enzyme stabilization of soil is commonly demonstrated in nature by termites for building mounds in tropical regions like Latin America, Africa and Asia. During the process of building mounds, termites cement the soil particles with salivary secretions and faecal excrements. This process increases the organic matter, carbon, calcium, phosphorous, potassium, magnesium and nitrogen $[1,32]$, and thus, leading to higher micro-aggregation of soil [25]. This leads to build of natural soil structures (termite mounds) which are rock hard and few meters tall, and also are known to stand firm despite heavy tropical rain seasons. The use of enzymes was initially developed in horticultural applications to improve the $\mathrm{pH}$, increase the organic matter and nutrients in the soils and thus improving the crop production $[10,43]$. Later, use of enzymes found its application in engineering and has been extensively used to improve the performance of soils for construction of roads, dams and airport runways, as it increases cohesion and stability, reduces permeability and helps in erosion control of the treated soil $[8,9,11-14,18,20,30]$.

\section{TerraZyme-enzyme stabilizer}

In this experimental programme, commercially available enzymatic stabilizer, namely TerraZyme was used. TerraZyme is a bio-enzyme in liquid form, which is formulated using vegetable extracts. They are perfectly soluble in water, brown in color and nontoxic in nature. The chemical composition is not revealed by the supplier due to the proprietary issues, and hence, it is very difficult to obtain the exact chemical composition of TerraZyme [15]. TerraZyme is specially formulated to modify the engineering properties of treated soil. They require dilution in water before application [35]. Several research studies on enzymatic stabilization have been undertaken in the past and were found to be effective in improving the soil properties [2, 4, 14, 19, 35-38, 40, 42]. Till recently, the reported information in the literature has mainly focused on evaluating the influence of TerraZyme in improving the soil properties through laboratory evaluation of changes induced in the plasticity properties of treated soils like Atterberg limits or through engineering property, namely unconfined compressive strength (UCS), and also improvements observed in the bearing capacity of TerraZyme treated subgrade 
soils as evidenced through the increase in California Bearing Ratio (CBR) values, and their actual performance over a certain period of time in the real time scenario. Only recently Zhang et al. [44] and Khan and Taha [16] have reported the changes observed at the microstructure level of TerraZyme treated soils with ageing as compared to that of untreated soil. They have reported that TerraZyme treatment of soils leads to agglomeration of particles at the microstructure level leading to the denser appearance of the microstructure as compared to that of the untreated soil. With this catalysing property, TerraZyme was considered as a suitable enzyme suitable to be used as a non-traditional stabilizer in this study.

\section{Methodology}

\section{Materials and methods}

In the present study, locally available tropical red earth, and TerraZyme (product from Nature Plus, Stratford, Connecticut, USA) were used. It was ensured that the selected soil was air dried, pulverized using a wooden mallet to break the clods and sieved through $4.75 \mathrm{~mm}$ sieve. The selected soil was characterized by its physical properties namely, liquid limit, plastic limit, shrinkage limit, particle size distribution, compaction characterisitics and specific gravity using the standard procedures as specified by Bureau of Indian Standards [6] and the results are summarized in Table 1. Based on the clay mineralogy as identified by the X-ray diffraction (Fig. 1), the natural red earth used in this study was identified to be kaolinitic in nature. This was also confirmed indirectly by the free swell ratio (FSR), which has been used as a simple parameter to identify the presence of principal clay mineral in the soil [26]. As the FSR value of soil used in this study is 1.2 , indicating the presence of kaolinite clay mineral in the soil.

Table 1 Physical Properties of Soil used in the present study

\begin{tabular}{lll}
\hline Sl. no. & Physical properties & Natural soil \\
\hline 1 & Specific gravity, Gs & 2.62 \\
& Atterberg limits and indices & \\
2 & Liquid limit, $\mathrm{W}_{\mathrm{L}}$ & 42.2 \\
3 & Plastic limit, $\mathrm{W}_{\mathrm{P}}$ & 22.8 \\
4 & Shrinkage limit, $\mathrm{w}_{\mathrm{S}}$ & 21.3 \\
5 & Plasticity index, $I_{\mathrm{p}}$ & 19.4 \\
6 & Shrinkage index, $I_{\mathrm{S}}$ & 20.9 \\
& Free swell test & \\
7 & Water & 12.0 \\
8 & Kerosene & 10.0 \\
9 & Free swell ratio & 1.2 \\
& Particle size distribution & 1 \\
10 & Gravel (\%) & 60 \\
11 & Sand (\%) & 18 \\
12 & Silt (\%) & 21 \\
13 & Clay (\%) & \\
& Compaction characteristics & 1.85 \\
14 & Maximum dry density (g/cc) & 15.7 \\
15 & Optimum moisture content (\%) & SC \\
\hline
\end{tabular}




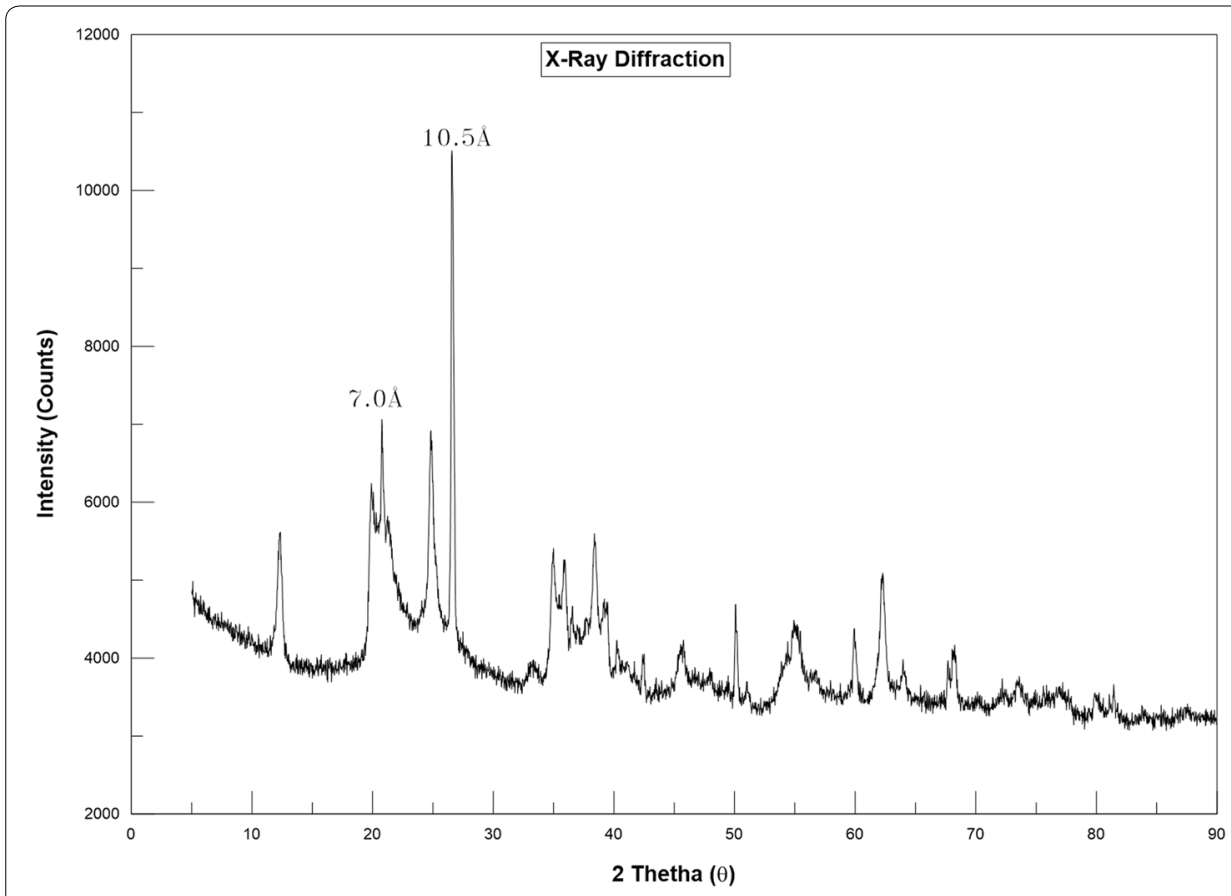

Fig. 1 X-ray diffraction of the natural soil

Table 2 Dosages of enzymes used in the present study

\begin{tabular}{llll}
\hline Sl. no. & Dosage notation & $\mathbf{2 0 0} \mathbf{~ m l / "} \mathbf{x}^{\mathbf{\prime}} \mathbf{~ m}^{\mathbf{3}}$ of soil & $\mathbf{~ m l} \mathbf{k g}$ of soil \\
\hline 1 & ST1 & 3.5 & 0.025 \\
2 & ST2 & 2.5 & 0.039 \\
3 & ST3 & 2.0 & 0.050 \\
4 & ST4 & 1.5 & 0.065 \\
\hline
\end{tabular}

\section{Dosage of TerraZyme}

It has been reported by Tingle et al. [41] that enzymes are active in the soil until no more reactions exist to catalyze. Since the enzymes act as a catalyst in initiating reactions in soil, they are required in very small dosages for stabilization purposes. As no technical standards have been established, its applicability relies on empirical guidelines set by previous studies [20]. Since varying dosages of the enzyme have different effects on the same soil, indicating that insufficient quantity of enzyme would not yield effective stabilization, while higher quantities may prove to have adverse effects on soil [35]. Hence, arriving at an optimal dosage of TerraZyme would be beneficial for increasing the efficacy of enzyme stabilization. The following dosages presented in Table 2 were considered for the present study.

\section{Experimental programme}

To understand the effect of TerraZyme on physical properties of enzyme treated soil, namely, liquid limit, plastic limit, plasticity index and shrinkage limit, the following experimental program was planned. Since, it is reported that treating the soil 
with TerraZyme has a time-related modification of soil properties, it was planned to study the effect of ageing on the plasticity properties. Based on the preliminary tests, it was observed that there were no changes in the evaluated physical properties of the soil immediately after the addition of TerraZyme to the soil, while there was marginal improvement in strength of the treated soil. Additionally, it is reported in the literature that changes in properties of soil due to stabilization effect of TerraZyme treatment can be significant only after 7 days and last up to 1-2 months [22, 27]. Hence, different ageing periods of 7, 14, 30 and 60 days were selected in this study, in order to understand the effect of TerraZyme with ageing.

For carrying out the experiments to evaluate the plasticity properties considering four selected ageing periods, it was felt that $1 \mathrm{~kg}$ of the selected soil passing through $425 \mu \mathrm{m}$ sieve would suffice. Accordingly, $1 \mathrm{~kg}$ of soil passing through $425 \mu \mathrm{m}$ sieve was taken for each dosage of TerraZyme treatment. For each of the dosages of TerraZyme as mentioned in Table 2, the required dosage of the stabilizer was carefully extracted through a clinical microsyringe (of $1 \mathrm{ml}$ maximum capacity), and then, injected to the water to be used for mixing the soil samples. This quantity of water selected was approximately near to the liquid limit values of the soil. After initial mixing of the soil with the TerraZyme injected water, any additional water required for mixing the soil sample was suitably added to bring the consistency of TerraZyme treated soil slightly more than the liquid limit, which was ascertained by the freeflowing condition of the soil. Each mixture of soil-TerraZyme prepared following the procedure as explained above was thoroughly mixed with a spatula for more than $30 \mathrm{~min}$, and the prepared samples were later transferred into polythene covers. These covers were properly sealed and placed in a desiccator to prevent loss of moisture. At the designated ageing periods, some portion of the sample was taken from each of the polythene covers and was tested for evaluating their plastcity properties.

Since TerraZyme is hydrophobic, it was felt necessary to understand the effect of TerraZyme and the suitable curing conditions on the strength characteristics of the treated soil. Hence, two separate sets of unconfined compressive soil specimens were prepared. Each set of specimens was prepared with different dosages of TerraZyme as mentioned in Table 2. TerraZyme was pre-injected to the calculated quantity of water to obtain soil specimens near to optimum moisture content (obtained based on the compaction test results). The calculated quantity of soil for obtaining a requisite number of soil specimens was thoroughly mixed with this TerraZyme injected water till a uniform consistency was obtained. After mixing the soil, it was transferred into a static compactor for preparing identical specimens having maximum dry density as obtained from standard proctor compaction test [7]. The statically compacted specimens were extruded from the mould, properly sealed with a moist cloth and stacked in a desiccator to avoid any moisture loss. All the specimens were properly labelled for future reference. One set of samples were cured, only once daily, through application of water using a wash bottle (wet curing), while another set of samples were kept in sealed condition with a wet cloth and placed in desiccator filled with water at the bottom of the plate on which specimens were stacked to maintain them in a saturated condition by the humid environment inside the desiccator (sealed curing). Different curing conditions namely, sealed curing and wet 
curing were done to understand the effect of type of curing for effective stabilization. The test specimens were tested for UCS at end ageing period of 7, 14, 30 and 60 days.

\section{Results and discussion}

\section{Effect of TerraZyme on physical properties of the soil}

With ageing, the addition of TerraZyme to the soil for all the dosages selected in this study has shown to reduce the liquid limit, and an increase in the plastic limit of the soil. Figure 2 shows the changes in the values of liquid limit and plastic limit of TerraZyme treated soil with ageing. It can be observed that the effect of TerraZyme on modifying the liquid limit of soil is more significant as compared to that on the plastic limit. This can be attributed to the fact that, at liquid limit, the water holding capacity of the soil is more compared to that at plastic limit, leading to a better electrolyte movement in the soil. This enhanced electrolyte movement would have enabled better interaction of TerraZyme with soil particles. Similar observations of a reduction in the liquid limit of red earths (kaolintic type of soils) were reported in the literature For e.g., [20, 33, 35]. Further, it is interesting to note that, though for all the four different dosages of TerraZyme used in this study have shown a reduction in the liquid limit, ST4 dosage of TerraZyme has found to be more effective than other dosages. The liquid limit of the natural soil used in this study was $42.2 \%$. At the end of 60 days of ageing, the liquid limit of the TerraZyme treated soil with different dosages of ST1, ST2, ST3 and ST4 was $41.6 \%, 39.6 \%, 38.8 \%$ and $38.2 \%$ respectively.

While, the liquid limit of the TerraZyme treated soil has shown a decrease in values with ageing, the plastic limit, on the other hand, has shown an increase with ageing. This may probably be due to the aggregation of soil particles as a result of the stabilizing effect of TerraZyme. The plastic limit of the natural soil used in this study was

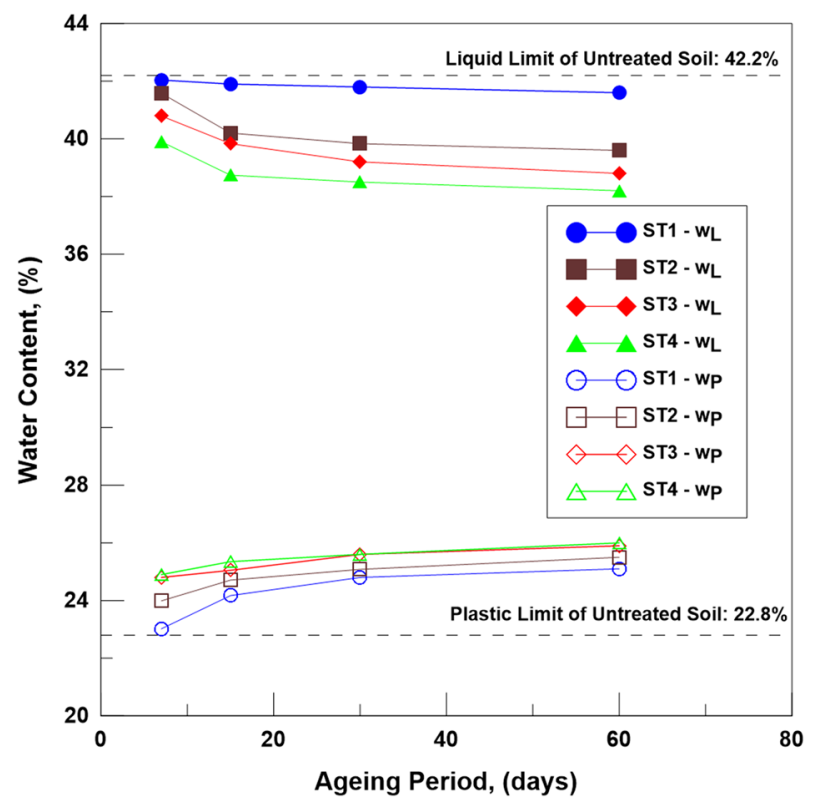

Fig. 2 Effect of enzymes on Atterberg limits 
$22.8 \%$. At end of 60 days of ageing, plastic limit of the TerraZyme treated soil with dosages ST1, ST2, ST3 and ST4 was respectively $25.1 \%, 25.5 \%, 25.9 \%$, and $26.0 \%$. This reduction of the liquid limit and an increase of the plastic limit of treated soil with ageing indicates that addition of TerraZyme to the soil has reduced its plasticity.

Based on the plasticity properties of the fines fraction, the position of untreated soil fines on the plasticity chart is above the A-line, indicating that the fines fraction is essentially clay. Hence, as per Indian soil classification system [5], the untreated soil is classified as SC: Clayey SAND (refer Table 1). As seen from Fig. 2, there is a noticeable variation of both liquid and plastic limit, and hence plasticity index of TerraZyme treated soil with ageing. These ageing related variations of liquid limit and plasticity index of TerraZyme treated soils affect the classification of the soil. Figure 3 shows the change in position of the soil fines on the plasticity chart based on the variation of the liquid limit and the plasticity indices with different dosages of TerraZyme namely, ST1, ST2, ST3 and ST4 at all ageing periods. It can be observed from Fig. 3, that with ageing the soil's position gradually changes from clayey fines (being above the A-line) for the untreated soil to silty fines (being below the A-line), this being more prominent for a higher dosage of TerraZyme. Thus, the untreated soil, which was a Clayey SAND (SC) before treatment with TerraZyme, has gradually changed into a Silty SAND (SM). Thus, from the changes observed in the plasticity index, it may indicate that there may be a change in soil structure (arrangement of clay particles) from relatively dispersed clayey fines to a relatively more flocculated silty fines. This would also imply that, more is the flocculated structure due the micro level interactions of TerraZyme at the points of contact, it may lead to a more stable structure, and hence, increased volumetric stability of the TerraZyme treated soil. Such inferences of changes in soil structure through changes in plasticity properties hitherto have not been reported in the literature. These inferences of changes

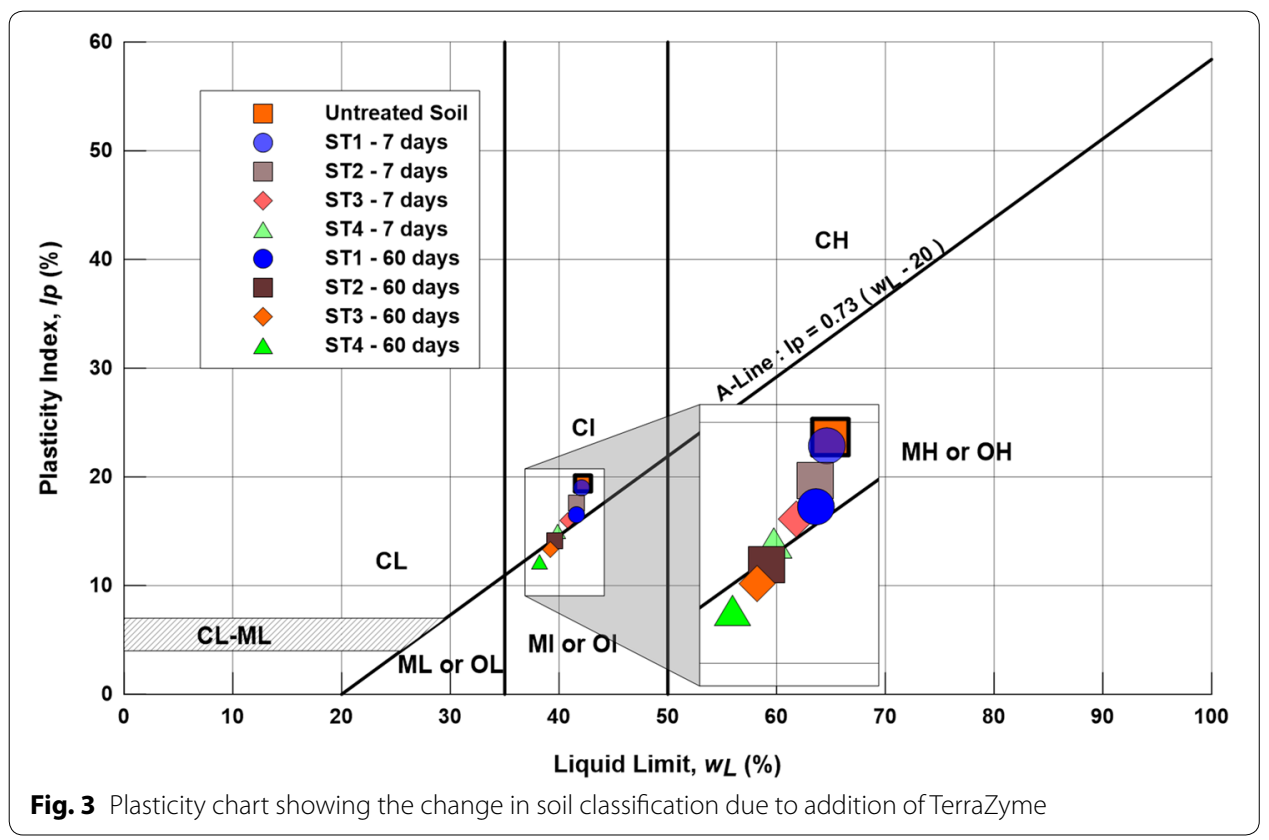




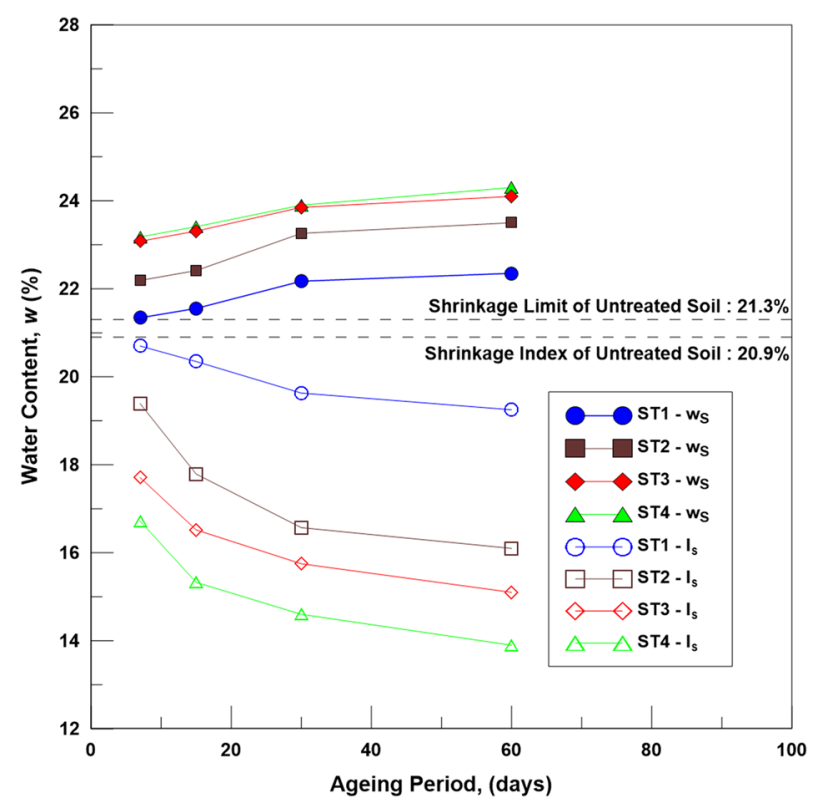

Fig. 4 Effect of enzymes on Shrinkage factors

in soil fabric from the observed changes in plasticity properties of the TerraZyme treated soil could be better understood by analyzing the variation in shrinkage limit with ageing.

On addition of TerraZyme to the soil, an increase in the shrinkage limit with ageing was observed as illustrated in Fig. 4. It can be seen from the figure, that at the end of 60 days of ageing period, shrinkage limit has gradually increased from $21.3 \%$ for the untreated soil to $22.3 \%, 23.5 \%, 24.1 \%$ and $24.3 \%$ for dosages ST1, ST2, ST3 and ST4 respectively. It is well understood that clays with more flocculated structure have higher values of shrinkage limit when compared to clays having relatively dispersed structure. Hence, the increase in shrinkage limit of TerraZyme treated soils indicates that the soil is becoming more flocculated with ageing. The more conspicuous changes in the physical property of treated soil with ageing that can be observed is the marked reduction in shrinkage index $\left(\mathrm{I}_{\mathrm{S}}=\mathrm{w}_{\mathrm{L}}-\mathrm{w}_{\mathrm{S}}\right.$; i.e., shrinkage index is the numerical difference in the values of liquid limit and shrinkage limit) $[23,39]$. Here the shrinkage index of the untreated soil is $20.9 \%$. The values of shrinkage indices of the treated soil with various proportions of TerraZyme at 60 days of ageing are 19.3\%, 16.1\%, 15.1\% and 13.9\% for dosages ST1, ST2, ST3 and ST4 respectively. It has been previously brought out by Nagaraj [23] and Sridharan and Nagaraj [39] that, the compressibility of soil has a better correlation with shrinkage index, and that for any soil, lower is the shrinkage index, less is the compressibility of the soil. This indirectly indicates that, a soil with clayey fines on being treated with an appropriate dosage of TerraZyme, can be transformed into a less compressible soil with ageing. This would imply that the TerraZyme treated soil becomes relatively more volumetrically stable and would be less prone to variation in volume changes, and thus, have better resistance in formation of cracks. It is observed that soils having a significant portion of clay in soil is prone to formation of cracks, and such soils are not recommended to be used in earthen construction [24]. Hence, the clay portion in the soil used in the preparation of 
earthen construction products like compressed earth blocks is usually restricted to $15 \%$ [29]. However, in the present study, it can be observed that clay portion is $21 \%$ which is higher than the recommended limit of 15\%. Even at higher clay content, the soil has been used to prepare CSEBs and the reported evaluated engineering properties are quite better with TerraZyme treatment as indicated by the wet compressive strength being nearly $50 \%$ more than the blocks prepared without TerraZyme [37, 38]. In addition, the blocks were observed to be quite durable as indicated by the loss in mass after being subjected to twelve cycles of alternate wetting and drying.

Various researchers have been trying to understand the interactions of enzyme at the micro level as reflected by the observed changes in the macro level behaviour. It has been reported in the literature that, the enzymes have a catalytic effect on the stabilization process of soil [20,33-35, 41]. Researchers have proposed two different stabilizing mechanisms of enzymes on the soil. One proposed stabilization mechanism is that, the enzymes that are present in treated soil are adsorbed by the clay lattice, and in turn cations are released as an exchange, a process similar to cation exchange. This leads to a reduction in the thickness of diffuse double layer of the clay [20,33, 34, 41]. It is additionally proposed by Scholen [34] that, the enzymes could bond with large organic molecules present in the soil, and together would be attracted to the clay minerals' net negative surface charge. The large organic molecules would then surround the clay minerals, neutralizing the negative charge and reducing the clay's affinity for moisture. Though the end result of both of the proposed mechanisms is a more stable clay lattice structure and a reduced affinity for moisture is valid theoretically, limited laboratory verification has been reported in the literature as suggested by Tingle et al. [41]. Further, they indicated that, as the proposed mechanisms suggest the reduced affinity of water, suitable shrink-swell tests would enable its validation. As the proposed mechanisms indicate the dependence of environmental conditions for effective stabilization, understanding the stabilization process at different working conditions would provide a better insight into the mechanisms. Results of observed changes in both plasticity index and shrinkage index as discussed above and the inferences that are drawn, clearly support the proposed mechanism by Scholen [33, 34] through which the stabilization of enzyme treated soil takes place. This encourages more detailed study to further the understanding of the mechanism of enzymatic stabilization.

\section{Effect of type of curing on strength characteristics of TerraZyme treated soil}

This experimental programme was taken up to understand the behaviour of TerraZyme treated soil to the type of curing, namely sealed curing and wet curing (continuous supply of water), and its effect on increasing the strength of the treated soil. A typical plot of axial stress versus strain for soil treated with a TerraZyme dosage of $0.025 \mathrm{ml} / \mathrm{kg}$ (ST1 dosage) at 60 days of ageing for both type of curing is presented in Fig. 5. It is interesting to observe from Fig. 5 that, the UCS of the soil for a given dosage of TerraZyme is higher for specimens that were sealed cured as compared to that of the specimens that were cured by external application of water. The comparably lower strength of samples cured by the latter method of curing may be due to the supply of water at regular intervals, which on its application might have percolated into the specimens and might have led to leaching of TerraZyme along with water due to gravity. It can be observed 


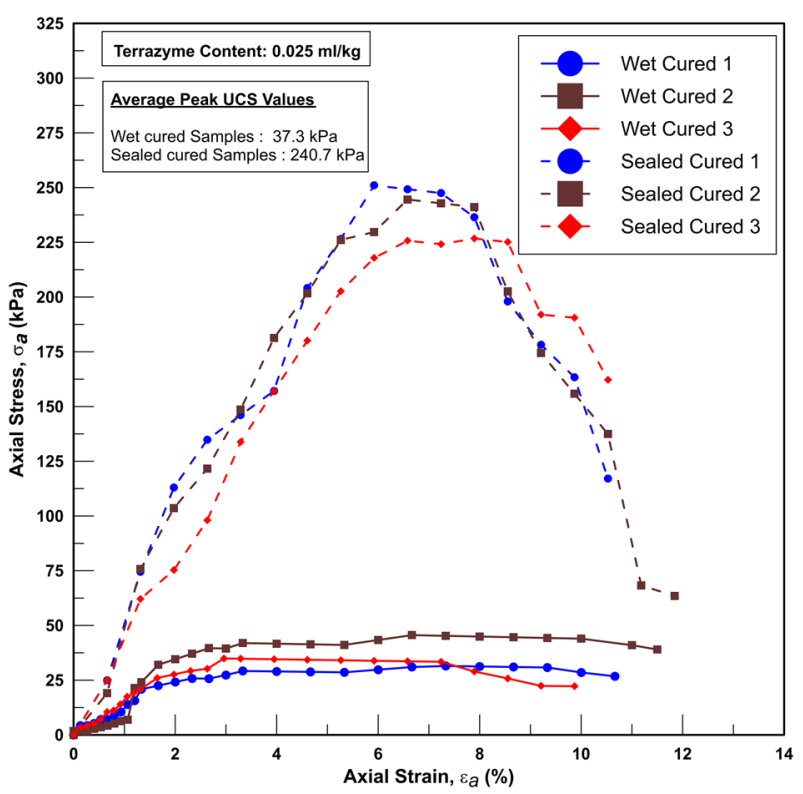

Fig. 5 Typical plot of axial stress versus strain for soil treated with a TerraZyme dosage of $0.025 \mathrm{ml} / \mathrm{kg}$ TerraZyme (ST1 dosage) at 60 days of ageing for both type of curing
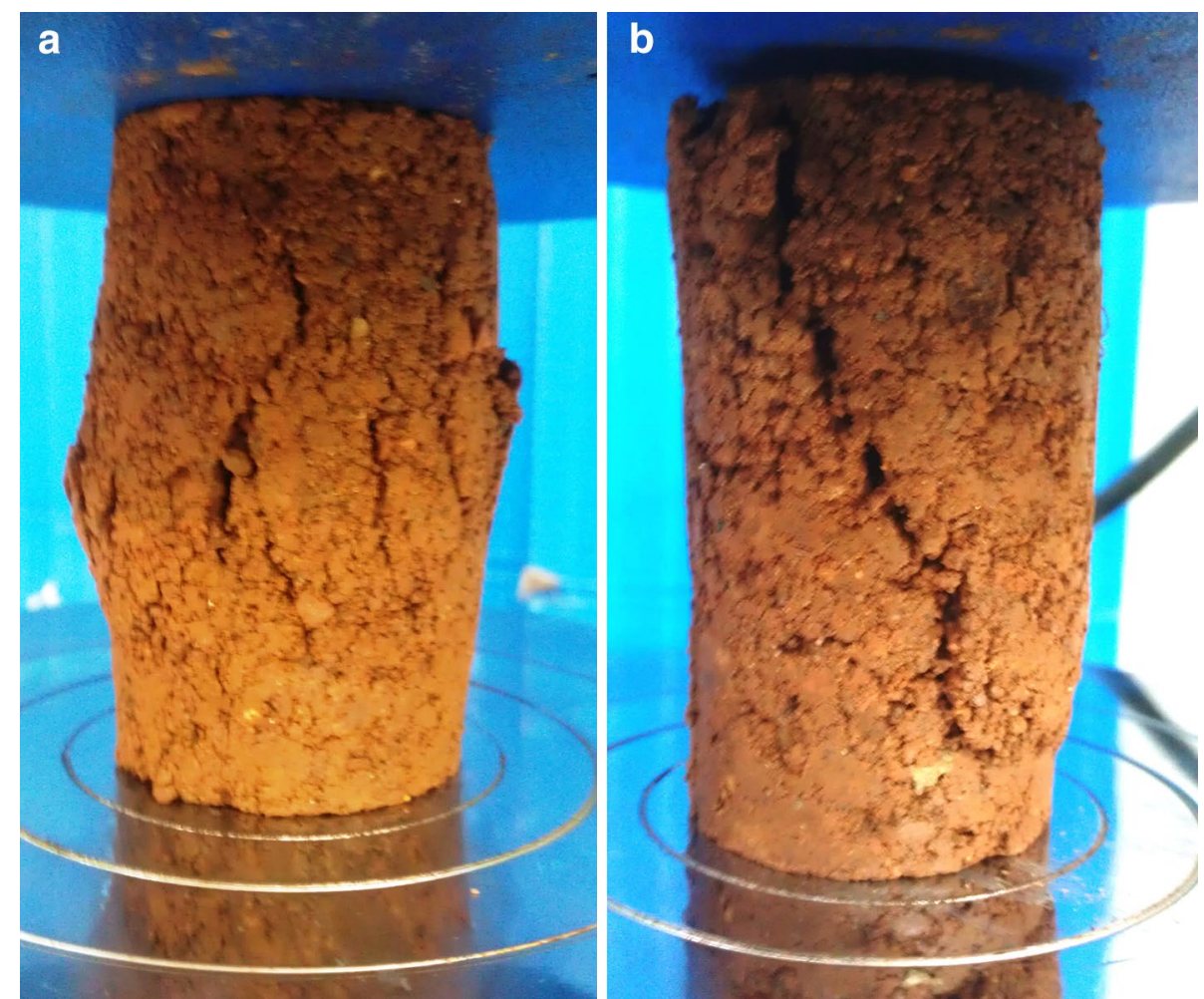

Fig. 6 a Typical shear failure pattern for wet cured specimens. b Typical shear failure pattern for sealed cured specimens 
that TerraZyme has a distinct effect in leading to the higher strength of the soil under sealed curing condition. Similar stress-strain behaviour was observed for soil treated with other selected dosages of TerraZyme used in this study and at different periods of ageing. Typical stress-strain behaviour for both types of curing are presented in Fig. 6a, b respectively. It can be observed from these figures that, wet cured specimens had bulged laterally with several shear failure planes indicating ductile behaviour, while the specimens that were sealed cured had a distinct shear failure indicating a semi-brittle behaviour.

Figure 7 is a plot of UCS of soil specimens treated with different dosages of TerraZyme for both types of curing versus ageing. It can be observed that, after 60 days of ageing, the strength of sealed cured soil specimens for all dosages were comparably very high as compared to that of wet cured soil specimens. The UCS of wet cured soil specimens was found to be 37.3, 66.6, 71.2 and $60.5 \mathrm{kPa}$ after 60 days of ageing for ST1, ST2, ST3 and ST4 respectively. The UCS of sealed cured soil specimens was found to be about 240, 398, 640 and $560 \mathrm{kPa}$ after 60 days of ageing for ST1, ST2, ST3 and ST4 respectively. It can also be observed that the strength of sealed curing soil specimens was about 10 times higher in strength to that of wet cured soil specimens. This research finding suggests that the proper way of curing the TerraZyme treated soil after its field application of TerraZyme is essential for improving its properties. It should be noted that in field conditions, TerraZyme would prove to be more beneficial under sealed curing condition i.e., no additional excess supply of water should be done for effective stabilization of the soil except maintaining adequate dampness. Supply of additional water would probably hinder the stabilization process of the TerraZyme treated soil.

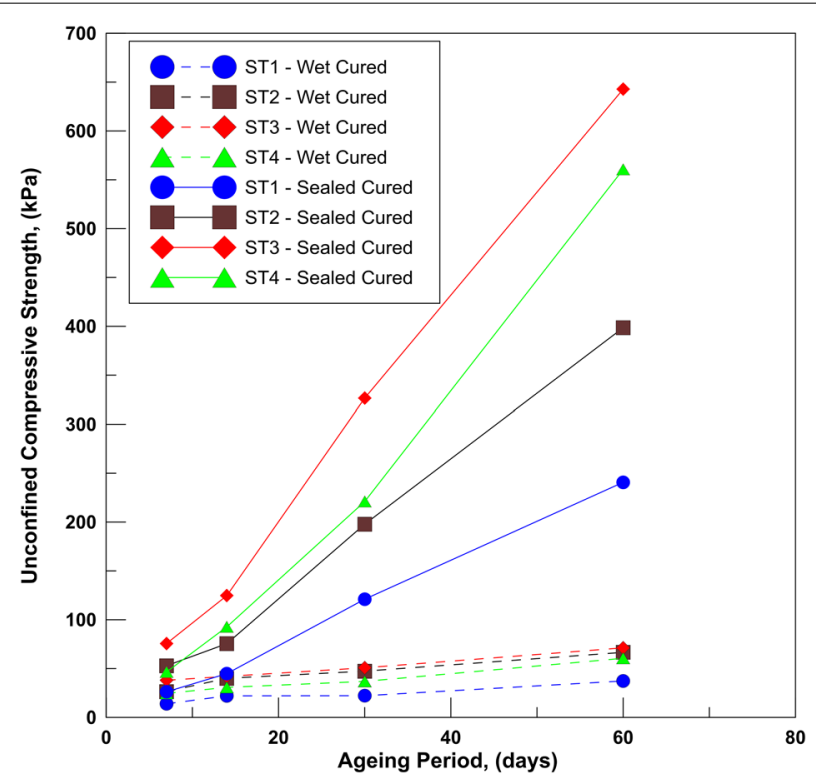

Fig. 7 Unconfined compressive strength versus ageing periods for all dosages of enzyme used in this study 


\section{Conclusions}

From this carefully carried out experimental program following important observations and inferences can be drawn:

1. From the results of the experimental study of changes in plasticity properties of TerraZyme treated soil, it was observed that even micro dosages of enzymes reduced its liquid limit with ageing, while the plastic and shrinkage limits have increased. The increase in shrinkage limit of enzyme treated soil with ageing is more prominent indicating that the soil is becoming more flocculated (open fabric, i.e., edge to face arrangement). Thus, there is a decrease in both plasticity index and shrinkage index. So, the untreated natural soil, which was a Clayey SAND (SC) before treatment with TerraZyme, gradually changed into a Silty SAND (SM). Thus, from the changes observed in the plasticity index, it may be inferred that there may be a change in soil structure from relatively dispersed clayey fines to a relatively more flocculated silty fines. These inferences of changes in soil structure from the observed changes in plasticity properties of the TerraZyme treated soil was supported by the prominent increase in shrinkage limit, and hence, a reduction in the shrinkage index with ageing. It is also well known that flocculated structure would have a better shear strength. Further, lesser is the shrinkage index, lesser is the compressibility, and hence, an increase in volumetric stability. These types of observations hitherto have not been reported in the literature. Thus, through simple index tests as presented and discussed in this paper, the authors have tried to experimentally infer that the postulated mechanisms by various researchers to be correct and acceptable.

2. Also, the observed increase in UCS strength of the TerraZyme treated soil with ageing indicates that change in soil structure to a relatively more flocculated structure may be related to this increase in strength. Further, it was observed that sealed curing condition of the soil was found to be more effective than wet curing method for strength gain of enzymes treated soil, thereby bringing out the suitable type of curing to be adopted in the field after application of enzymes to the soil.

3. The results from this study bring out the potential benefits of using enzymatic stabilization to reduce the plasticity properties and increase volumetric stability of soil, thus making the soil less susceptible to crack formation. This beneficial effect of making the soil volumetrically stable and less susceptible to crack formation can be effectively used for stabilised earthen construction elements like rammed earth, CSEBs and adobe blocks. Further, the improvement of the strength as noted from UCS tests, indicate that small addition of enzymes would help in improving the strength of the unstabilised earthen construction.

\section{Abbreviations}

$W_{\llcorner}$: liquid limit of the soil; $w_{p}$ : plastic limit of the soil; $w_{s}$ : shrinkage limit of the soil; $I_{p}$ : plasticity index of the soil; $I_{s}$ : shrinkage index of the soil.

\section{Authors' contribution}

SM and HBN carried out the experiments, complied the results, participated in the sequence alignment and drafted the manuscript. Both authors read and approved the final manuscript. 


\section{Author details}

${ }^{1}$ Laboratoire SIAME Université de Pau et des Pays de I'Adour, 64600 Anglet, France. ${ }^{2}$ Department of Civil Engineering, B.M.S. College of Engineering, Bangalore, Karnataka 560019, India.

\section{Acknowledgements}

The authors would like to acknowledge Mr. Apoorva Modi from M/s Avijeet Agencies, Chennai, India for providing sufficient quantity of TerraZyme used for this research study.

\section{Competing interests}

The authors declare that they have no competing interests.

\section{Publisher's Note}

Springer Nature remains neutral with regard to jurisdictional claims in published maps and institutional affiliations.

Received: 2 June 2017 Accepted: 18 January 2019

Published online: 05 February 2019

\section{References}

1. Ackerman IL, Teixeira WG, Riha SJ, Lehmann J, Fernandes ECM (2007) The impact of mound-building termites on surface soil properties in a secondary forest of Central Amazonia. Appl Soil Ecol 37:267-276

2. Baby M, Gowshik A, Rajeshwar AVK, Mohanasundram M (2016) Experimental study of expansive soil stabilized with TerraZyme. Int J Eng Res Technol 5:897-899

3. Bajpai P (2014) Non-conventional soil stabilization techniques the way forward to an aggregate free pavement and a cost effective method of road construction. Int J Sci Eng Res 5:1063

4. Bergmann R (2000) Soil stabilizer on universally accessible trials. FHWA, San Dimas

5. BIS (1970) Indian standard IS 1498: classification and identification of soil for general engineering purposes. Bureau of Indian Standards, New Delhi

6. BIS (1987) Indian standard SP-36 part 1: compendium of indian standards on soil engineering-laboratory testing of soils for civil engineering purposes. Bureau of Indian Standards, New Delh

7. BIS (1999) Indian standard-2720 part 7: methods of test for soils: determination of water content-dry density relation using light compaction. New Delhi, Bureau of Indian Standards

8. Brazetti R (1998) Considerations about the influence of different additives in organic micromorphological, mineralogical, physical, mechanical and hydraulics characteristics of a lateritic soil. Escola Politecnica de Sao Paulo, Sao Paulo

9. Brazetti R, Murphy SR (2001) Objective performance measurement of actual road sites treated with an organic soil stabilizer. In: First road transportation technology transfer conference in Africa, Dar Es Salaam, Tanzania

10. Fageria NK, Baligar VC (2005) Properties of termite mound soils and responses of rice and bean to nitrogen, phosphorus, and potassium fertilization on such soil. Commun Soil Sci Plant Anal 35:2097-2109

11. Guthrie WS, Simmons DO, Eggett DL (2015) Enzyme stabilization of low-volume gravel roads. Transp Res Rec J Transp Res Board 2511:112-120

12. Hitam A, Yusof AZ, Samad O (1999) Soil Stabilizer for plantation road. In: National seminar on mechanization in oil palm plantation

13. Hong Z, Liu S, Shen S, Negami T (2006) Comparison in undrained shear strength between undisturbed and remolded Ariake clays. J Geotech Geoenviron Eng 132:272-275

14. Isaac KP, Biju PB, Veeraragavan A (2003) Soil stabilization using bio-enzyme for rural roads. In: Integrated development of rural an arterial road networks for socio-economic development, Delhi

15. Kestler M (2009) Stabilization selection guide for aggregate-and native-surfaced low-volume roads. US Department of Agriculture, Forest Service, National Technology \& Development Program

16. Khan TA, Taha MR (2015) Effect of three bioenzymes on compaction, consistency limits, and strength characteristics of a sedimentary residual soil. Adv Mater Sci Eng 1:1-9

17. Lax C (2010) Life cycle assessment of rammed earth. Univeristy of Bath

18. Li YJ, Li L, Dan HC (2011) Study on application of TerraZyme in road base course of road. Appl Mech Mater 97:1098-1108

19. Manoj S, Sunil B, Sikdar PK (2003) Bio-enzyme for stabilization of soil in road construction a cost effective approach. In: Integrated development of rural and arterial road networks for socio-economic development, New Delhi

20. Marasteanu M, Hozalski R, Clyne TR, Velasquez R (2005) Preliminary laboratory investigation of enzyme solutions as a soil stabiliser, Minnesota Department of Transportation Research

21. Moloisane RJ, Visser AT (2014) Evaluation of the strength behaviour of unpaved road material treated with electrochemical-based non-traditional soil stabilisation additives. J S Afr Inst Civil Eng 56:28-39

22. Naagesh S, Gangadhara S (2010) Swelling properties of bio-enzyme treated expansive soil. Int J Eng Stud 2:155-159

23. Nagaraj HB (2000) Prediction of engineering properties of fine-grained soils from their index properties. Indian Institute of Science, Bangalore

24. NZS 4298 (1998) Materials and workmanship for earth buildings [building code compliance document E2 (AS2)]

25. Pereira HN (2011) Saliva de Cupim: recent experiments with termite mound soil and termite saliva as stabilizers for earthen structures. In: Terra 2008: the 10th international conference on the study and conservation of earthen architectural heritage, Getty Publications, p 247

26. Prakash K, Sridharan A (2004) Free swell ratio and clay mineralogy of fine-grained soils. Geotech Test J 27:220-225 
27. Ramesh HN, Sagar SR (2015) Effect of drying on the strength properties of TerraZyme treated expansive and nonexpansive soils. In: 50th Indian geotechnical conference, Pune, India

28. Rauch AF, Harmon JS, Katz LE, Liljestrand HM (2002) Measured effects of liquid soil stabilizers on engineering properties of clay. Transp Res Rec 1787:33-41

29. Reddy BVV, Lal R, Rao KN (2007) Optimum soil grading for the soil-cement blocks. J Mater Civil Eng 19:139-148

30. Renforth P, Manning DAC, Lopez-Capel E (2009) Carbonate precipitation in artificial soils as a sink for atmospheric carbon dioxide. Appl Geochem 24:1757-1764

31. Renjith R, Robert D, Fuller A, Setunge S, O'Donnell B, Nucifora R (2017) Enzyme based soil stabilization for unpaved road construction. In: MATEC web of conferences, EDP Sciences, p 1002

32. Sarcinelli TS, Schaefer CEGR, Fernandes Filho El, Mafia RG, Neri AV (2013) Soil modification by termites in a sandy-soil vegetation in the Brazilian Atlantic rain forest. J Trop Ecol 29:439

33. Scholen DE (1992) Non-standard stabilizers. FHWA, US Department of Transportation, Washington, D.C

34. Scholen DE (1995) Stabilizer mechanisms in nonstandard stabilizers. In: Transportation research board conference proceedings

35. Shankar AUR, Rai HK, Mithanthaya RI (2009) Bio-enzyme stabilised laterite soil as a highway material. J Indian Roads Congr 70:143-151

36. Shukla M, Bose S, Sikdar P (2010) Bio-enzyme for stabilization of soil in road construction a cost effective approach. In: Integrated development of rural and arterial road networks for socio-economic development, New Delhi

37. Sravan MV, Nagaraj HB (2017) Potential use of enzymes in the preparation of compressed stabilized earth blocks. J Mater Civil Eng 29:04017103

38. Sravan MV, Nagaraj HB (2015) Preliminary study on use of TerraZyme as a bio stabilizer along with cement and lime in compressed stabilized earth blocks. In: First international conference on bio-based building materials, ClermontFerrand, pp 1-8

39. Sridharan A, Nagaraj HB (2000) Compressibility behaviour of remoulded, fine-grained soils and correlation with index properties. Can Geotech J 37:712-722

40. Thomas A, Tripathi RK, Yadu LK (2016) Effect of enzymes on the unconfined compressive strength of soil. Int J Appl Eng Res 11:6940-6942

41. Tingle J, Newman J, Larson S, Weiss C, Rushing J (2007) Stabilization mechanisms of nontraditional additives. Transp Res Rec J Transp Res Board 1989:59-67

42. Venkatasubramanian C, Dhinakaran G (2011) Effect of bio-enzymatic soil stabilisation on unconfined compressive strength and California bearing ratio. J Eng Appl Sci 6:295-298

43. Watson JP (1977) The use of mounds of the termite Macrotermes falciger (Gerstäcker) as a soil amendment. J Soil Sci 28:664-672

44. Zhang X, Zhang XP, Peng HT, Xia Q, Wang J (2013) Relation of microstructure and unconfined compression strength of soil stabilized with TerraZyme. Adv Mater Res 664:760-763

\section{Submit your manuscript to a SpringerOpen ${ }^{\circ}$ journal and benefit from:}

- Convenient online submission

- Rigorous peer review

- Open access: articles freely available online

- High visibility within the field

Retaining the copyright to your article

Submit your next manuscript at $\gg$ springeropen.com 